\title{
Species Diversity of Sea Stars Along the Intertidal Zones of Selected Areas in Davao Gulf, Philippines
}

\author{
Melodie Claire Waay-Juico ${ }^{1}$ \\ ${ }^{1}$ Department of Biology, Davao Doctors College, General Malvar St., Davao City, Philippines \\ Correspondence: Melodie Claire Waay-Juico, Department of Biology, Davao Doctors College, General Malvar St., \\ Davao City, Philippines. E-mail: bio@davaodoctors.edu.ph, melodie_claire@yahoo.com
}

Received: July 15, $2014 \quad$ Accepted: August 4, $2014 \quad$ Online Published: September 02, 2014
doi:10.5539/enrr.v4n4p51
URL: http://dx.doi.org/10.5539/enrr.v4n4p51

\begin{abstract}
This study was undertaken to provide biological information on the species distribution and abundance of sea stars as well as the physico-chemical status of the seawater of selected intertidal zones of Davao Gulf for sustainable use of marine resources. This study was conducted along the 10 selected intertidal zones of Davao Gulf specifically in Davao City, Philippines. Results showed a total of 2357 individuals identified. These species belong to 8 genera and 4 families of sea stars. Of these, 1842 species belong to family Astropectinidae, 484 species are under the family of Ophidiasteridae, 30 species for family Oreasteridae, and 1 species in the family of Acanthasteridae.

Sampling was done from September 2010 to March 2011. The study revealed a diversity index of $28.45 \%$ using Shannon-Weiner showing low species richness and evenness. Majority of the sampling area $(80 \%)$ are composed of sandy substrate while $20 \%$ have silty and muddy substrate. Of the sandy substrate, $30 \%$ of which have coral rubble, $40 \%$ have sea grasses and only $10 \%$ were observed with living corals. Species richness generally increases with increasing water quality, habitat diversity and or habitat suitability and is expected to decrease with human induced disturbance. Although statistics revealed there were no significant relationship between the number of sea star species and the physico-chemical parameters except for the BOD which recorded a much lower value compared to the criteria set by the government. Literature readings cites the possibility that the temperature might be the cause of the sudden change of BOD since temperature affects the rate of photosynthesis of plants, the metabolic rate of aquatic animals, rates of development, timing and success of reproduction, mobility, migration patterns and the sensitivity of organisms to toxins, parasites and diseases.
\end{abstract}

Keywords: Davao Gulf, intertidal zones, Philippines, sea stars, species diversity

\section{Introduction}

Davao Gulf is a 308,000-hectare body of water, located in Mindanao, Philippines. It covers the coast of the southernmost tip of Davao Del Sur, to Davao City and Davao Del Norte and continues to line the shores of Compostela Valley (Sun Star Davao, 2011). The Davao Gulf is one of the most diverse marine ecosystems in the world according to the World Wildlife Foundation (WWF, 2011). Reef and mangrove species, cetaceans and a host of invertebrates contribute to the natural diversity of the Gulf.

Invertebrates such as sea stars or commonly known as starfish is a natural inhabitant of Davao Gulf. Sea stars belong to Kingdom Animalia, phylum Echinodermata of class Asteroidea. Asteroids typically have five arms radiating outward from their central disks where their mouths open toward the bottom. All have podia or tube feet projecting down along the grooves on the undersides of the arms (Fenner, 2009). Sea stars are conspicuous and successful bottom-dwelling animals that can survive without food for months and feed on almost every type of marine organism encountered on the seabed. The greatest diversity of sea stars occurs in coastal regions, although as a group, they are well represented globally from the Antarctic, Pacific, Atlantic, and Indian Oceans where they inhabit mostly wave-exposed intertidal zones of coastal waters (Freeman, 2005). They are ecologically important because they can be important predators of other invertebrates like clams, barnacles and other attached marine life. Some crabs, fish, birds, and other echinoderms are known to prey on sea stars. Usually, they feed on arm tips, as their calcified bodies are difficult to eat and not very nutritious (Fell, 2008).

Echinoderm diversity is generally correlated with diversity of other invertebrates in the same environment; hence they are present where key indicators of high biodiversity hold for other taxa. The ability to measure biodiversity is 
critically important, given the soaring rates of species extinction and human alteration of natural habitats. Environmental gradients include both resource gradients such as water or soil nutrients for plants and gradients in conditions such as temperature and $\mathrm{pH}$. Patterns of species richness across gradients depend on the interactions between individual species' ranges of tolerance and competition (Brown et al., 2007).

It is a fact that marine ecosystems are among the most sensitive ecosystems. The interface between the land and sea is particularly vulnerable to various biological, physical chemical and natural factors. These coastal regions are where the majority of humans live and where the majority of human induced impacts occur. Increasing threats to the coastal environment due to human development, pollution and overharvesting has created a need for more information on the health of coastal habitats. Habitat modification poses the greatest threat to sea star diversity. In shallow waters, over-harvesting for ornamental trade is possible as well as the damaging effects of tourism (Muller, 2008).

Bos, et. al conducted a study in 2008 at Davao Gulf on the population biology of the horned sea star (Protoreaster nodosus) and has found out that it dominate sand and seagrass habitats. Macroinvertebrate assessments are effectively used as a planning tool for managing water uses, for ambient monitoring and for evaluating the effectiveness of pollution control measures because they are differentially sensitive to pollutants of various types and react to it quickly, they are ubiquitous, abundant and relatively easy to collect, their identification and enumeration is not as tedious and difficult to do. Benthic macroinvertebrates such as seastars are relatively sedentary and are therefore representative of local conditions and they have life spans long enough to provide a record of environmental quality (Paterson, 2008).

On the other hand, analysis on marine waters in the Philippines showed that the minimum temperature in the $21 \mathrm{st}$ century is expected to be higher than the 1961-90 baseline thereby a much warmer environment is projected that could lead to disruption on coastal flora and fauna (Capili et al., 2005).

The current status of biological knowledge of sea stars as well as the physico-chemical factors of the waters of Davao Gulf need to be extended to better understand the seastar population processes for appropriate conservation and protection measures. The general objective of this study was to correlate the species richness of intertidal zone sea stars with habitat type and key physico-chemical factors in the waters of Davao Gulf particularly in Davao City. Specifically, this study aimed (1) to determine the physico-chemical parameters in each sampling stations such as temperature, salinity, pH, dissolved Oxygen and Biological Oxygen Demand; (2) to compare the abundance of seastars among the 10 selected sampling stations in Davao City; (3) to collect representative samples of sea star species along the intertidal coast of Davao City area for taxonomic references; (4) to provide a species inventory of sea stars to serve as baseline information for future economic and scientific endeavors in Davao City area; and (5) to provide necessary recommendations for sustainability of Davao City marine ecosystem.

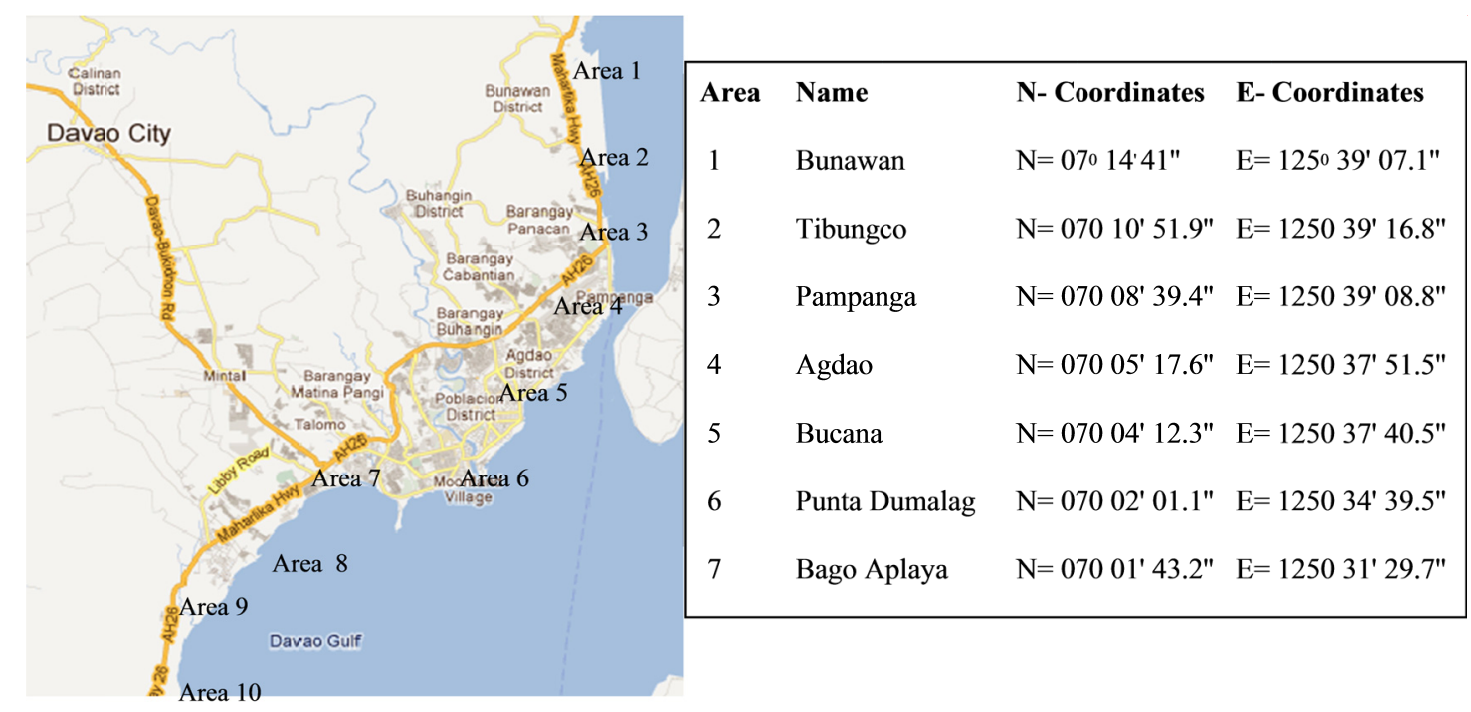

Figure 1. Map Of Davao Gulf Indicating The Sampling Areas And Its Coordinates 


\section{Methods}

\subsection{Preliminaries}

Clearance from the Department of Environment and Natural Office Region XI for the approval and release of the gratuitous permit was sought before the conduct of the study. This was followed by sending letters seeking permission to all Barangay Captains of the Local Government Units of the selected sites asking for authorization to conduct the study in their area.

\subsection{Research Area}

Ten (10) randomly selected sampling sites were chosen which includes the following intertidal zones in Davao City: Binugao, Dumoy, Bago Aplaya, Punta Dumalag, Bucana, Agdao, Pampanga, Sasa, Tibungco and Bunawan. Their coordinates are presented in Figure 1.

\subsection{Sea Star Sampling and Identification}

Five (5) 100 meter transect lines were laid out on the intertidal zones from the baseline (Figure 2). Seastars found within the width of 4 meters in each transect line were counted and identified. Specimens collected were identified to the species level as much as possible utilizing the Echinoderm Field Guide by Schoppe (2000) and World Asteroidea Database (Mah, 2008). Habitat of each sampling area was noted and recorded based on the Davao Doctors College Ecology Manual (SY 2006-07). The organisms were photographed and identified, the individuals in each taxonomic category were counted and the numbers were then recorded on data sheets. Sampling was done once every other month from September 2010 to February 2011. A representative sea star in each species was collected, dried and preserved and properly labeled for taxonomic reference.

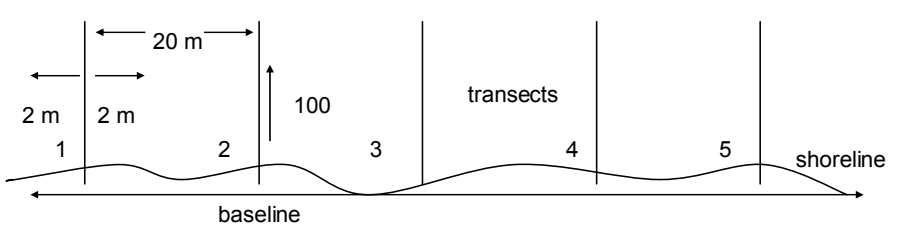

Figure 2. Lay-out of Sampling Area

\subsection{Determination of Physico-Chemical Parameters of Seawater}

Physico-chemical parameters were recorded such as pH, Dissolved Oxygen (DO), Biochemical Oxygen Demand (BOD), salinity and temperature once every other month from September 2010 to February 2011. The results were then referred to the Department of Environment and Natural Resources (DENR) Administrative Order \#34 on Water Quality and Classification.

\subsection{Data Analysis}

In dealing with the data gathered, results were tallied, tabulated and analyzed. The following statistical methods were utilized in this study: Shannon-Weiner Diversity Index, percentage of sea stars species in the given area and $\mathrm{t}$-test to get the significance level between the species richness of the intertidal zone sea stars with habitat type and the physico-chemical factors in the waters of Davao Gulf, Philippines.

\section{Results and Discussions}

\subsection{Species Composition}

A total of 2357 individuals were identified along the intertidal zones of Davao Gulf in Davao City, Philippines. These species belong to 8 genera and 4 families of sea stars. Of these, 1842 species belong to family Astropectinidae, 484 species are under the family of Ophidiasteridae, 30 species for family Oreasteridae, and 1 species in the family of Acanthasteridae. Uneven distribution of sea star species is attributed to the difference in the type of habitat and its food sources. Majority of the sea stars were Astropecten polyacanthus since these sea stars are common in sandy intertidal areas and sea grass beds distinctive of the habitat of area 1 and area 3 . Area 3 had $63.1 \%$ of the total number of sea stars found while area 3 has $13.8 \%$. This type of habitat is ideal for the sea stars to obtain food and to burrow in the substrate during daytime and becomes active at night (Schoppe, 2000). Linckia laevigata were found in abundance at Area 6 since these species occur in shallow reef areas exposed to sunlight where it feeds on algae and detritus (Schoppe, 2000). Area 6 ranked second as the station with the most number of sea star population with $19 \%$ sea stars found. Protoreaster nodosus were found in 2 sampling areas namely area 3 and area 6 since its common habitat is sea grass meadows in shallow water where it searches for food particularly 
sponges, soft corals and other small invertebrates. The existence of living corals at Area 6 indicates the presence of Culcita novaeguineae and Acanthaster planci since this is their primary habitat with plenty of food sources. On the other hand, Choriaster granulatus and Nardoa spp. which usually lives in water reefs from 3 meters to 40 meters deep were found in Area 9 with only $0.05 \%$ sea star population which could be attributed to their nature of being active during daytime searching for food (Schoppe, 2000). Furthermore, the differences in species composition recorded could be attributed to the ecological differences of the different geographical locations as shown on the other areas which exhibited a less than $2 \%$ of sea star population.

The low abundance of majority of the sea stars, composition and diversity recorded in this study may be attributed to stress imposed by indiscriminate anthropogenic activities (Ajao et al., 1996) such as industrial effluent discharge, oil wastes, domestic waste, and sewage discharges among others as human related activities are capable and presently destroying the sensitive coastal environment (Balogun et al., 2011).

The study revealed a diversity index of $28.45 \%$ using Shannon-Weiner Diversity Index indicating low species richness and evenness in the intertidal zones of Davao Gulf in Davao City, Philippines (Table 1). Ketcham (2001) in his study states that species richness generally increases with increasing water quality, habitat diversity, and or habitat suitability and is expected to decrease with human induced disturbance according to EcoGov (2006). It is further reported by the Davao City Coastal Zone Management Situation and Recommendations (2006) that the coastal waters of Davao Gulf are used in various ways such as fishing, navigation, tourism, and even for settlements. There is also a growing establishment of commercial centers and fishing grounds which are important sources of livelihood and income for a significant portion of Davao City's population.

Table 1. Species Richness and Distribution of Sea stars

\begin{tabular}{|c|c|c|c|c|}
\hline $\begin{array}{c}\text { Area } \\
\left(2000 \mathrm{~m}^{2}\right)\end{array}$ & Species observed & $\begin{array}{l}\text { total \# of } \\
\text { organisms }\end{array}$ & $\begin{array}{l}\text { species } \\
\text { richness }\end{array}$ & $\begin{array}{c}\text { species } \\
\text { diversity index }\end{array}$ \\
\hline 1 & Astropecten polyacanthus & 325 & 0.06 & 0 \\
\hline 2 & Astropecten polyacanthus & 42 & 0.15 & 0 \\
\hline 3 & $\begin{array}{c}\text { Astropecten polyacanthus, } \\
\text { Protoreaster nodosus, Nordoa spp. }\end{array}$ & 1488 & 0.10 & 0.102 \\
\hline \multicolumn{5}{|l|}{4} \\
\hline \multicolumn{5}{|l|}{5} \\
\hline 6 & $\begin{array}{c}\text { Linkia laevegata, Culcita novaeguineae, } \\
\text { Acanthaster planci, Protoreaster nodosus, } \\
\text { Astropecten polyacanthus }\end{array}$ & 448 & 0.24 & 0.197 \\
\hline 7 & Linckia laevigata, Astropecten polyacanthus & 26 & 0.39 & 0.429 \\
\hline 8 & Linckia laevigata, Astropecten polyacanthus & 16 & 0.50 & 0.377 \\
\hline 9 & Linckia laevigata, Choriaster granulatus & 12 & 0.87 & 0.918 \\
\hline 10 & & & & \\
\hline
\end{tabular}

\subsection{Habitat Type}

Results of the study disclosed that majority of the sampling area (80\%) are composed of sandy substrate while $20 \%$ have silty and muddy substrate. Of the sandy substrate, $30 \%$ of which have coral rubble, $40 \%$ have sea grasses and only $10 \%$ observed with living corals. Bleakley reported in 2004 that the diversity of coastal marine ecosystems at any point depends also on the variety of habitats and the importance of terrestrial influences. He further states that the destruction of coastal wetlands, removal of mangrove areas and alteration of the coastline for coastal development in the Pacific continue to occur in a largely uncoordinated and disintegrated fashion. Sea grass beds are declining in abundance and diversity from west to east across the Pacific. Beaches are also affected by coastal construction which can change currents and greatly alter sand deposition and erosion regimes. This situation is not far from happening in the coastal waters of Davao City as majority of the coastal areas are now used as settlement centers, commercial centers and fishing grounds as reported by Davao City Coastal Zone Management Situation and Recommendations in 2006. 


\subsection{Physico-Chemical Parameters of Seawater}

The mean physico-chemical results of the seawater is computed and the gathered data were assessed based on the Administrative Order \#34 of the Revised Water Usage and Classification/Water Quality Criteria Section 68 of the Philippine Coastal and Marine Waters. Nine of the ten sampling areas belong to Class SB as Recreational Water Class I or areas regularly used by the public for bathing, swimming, skin diving, etc. While sampling Area 6 belong to Class SC as marshy and or/mangrove areas declared as fish or wildlife sanctuaries, in which, this is the area where the Pawikan (Sea Turtle) Sanctuary is located.

Parameters such as the Dissolved Oxygen (DO) level in all sampling areas were found to be within the normal levels as set by the government. Temperature readings in all ten sampling areas were within the recorded at the site. Salinity levels were recorded to be within the range for marine water. The $\mathrm{pH}$ levels were within the range of $7-9$ which complies with the normal levels for marine water.

In this case, statistics revealed that there is no significant relationship between the physico-chemical characteristics and the number of sea star species as represented by the p-value of close to zero (Table 2). Although Brown, et. al. (2007) confirmed in his study that environmental gradients such as temperature and $\mathrm{pH}$ have an effect on the patterns of species richness. Waterwatch (2011) presented other parameters for water quality that may be tested which include turbidity, salinity and nitrates which could contributed to the distribution and species richness of the marine macroinvertebrates.

Table 2. Correlation results between sea stars species and physico-chemical parameters

\begin{tabular}{ccccccc}
\hline Areas & \# of Species & Mean DO & Mean salinity & Mean BOD & Mean temp. & Mean pH \\
\hline 1 & 325 & 8.12 & 2.27 & 2.50 & 29.70 & 8.12 \\
2 & 42 & 6.69 & 2.03 & 1.50 & 30.70 & 8.10 \\
3 & 1488 & 7.19 & 2.13 & 2.00 & 30.40 & 8.11 \\
4 & 0 & 6.45 & 2.00 & 3.70 & 33.00 & 8.15 \\
5 & 0 & 7.50 & 2.03 & 2.00 & 30.60 & 8.08 \\
6 & 448 & 10.30 & 2.00 & 2.00 & 32.00 & 8.27 \\
7 & 26 & 6.52 & 2.00 & 1.00 & 30.00 & 8.18 \\
8 & 16 & 7.47 & 2.00 & 2.00 & 29.30 & 8.20 \\
9 & 12 & 6.81 & 2.00 & 2.00 & 29.20 & 7.96 \\
10 & 0 & 7.45 & 1.73 & 2.30 & 30.60 & 7.90 \\
p-value & & 0.22029 & 0.42891 & -0.0413 & 0.03344 & 0.17660 \\
\hline
\end{tabular}

On the other hand, the Biological Oxygen Demand (BOD) for Class SB should be $5 \mathrm{mg} / \mathrm{L}$ which all sampling areas recorded a much lower value. A lower BOD value was also recorded for Class SC which should be at $7 \mathrm{mg} / \mathrm{L}$. Thus, statistics revealed a strong negative correlation with the number of species of sea stars in all ten selected intertidal zones with BOD level. This could be because there are low species richness recorded which utilizes oxygen in the said areas. There is also a possibility that the temperature might be the cause of the sudden change of BOD since temperature affects the rate of photosynthesis of plants, the metabolic rate of aquatic animals, rates of development, timing and success of reproduction, mobility, migration patterns and the sensitivity of organisms to toxins, parasites and disease (Waterwatch, 2011).

\section{Conclusion and Recommendation}

The results revealed a low seastar species richness and evenness that may be due to other factors rather than the physicochemical factors alone. It could be due to sparse seagrass cover, uneven coral growth and difference of substrate composition which limits the breeding grounds and food sources of the seastars. Another reason is due to some anthropogenic activities such as coastal development, pollution and growing illegal settlers along Davao Gulf. Thus, the following recommendations were proposed:

A more intensive study of the entire Davao Gulf and a thorough monitoring is needed to provide necessary recommendations for sustainability of Davao's marine ecosystem. For the future development of the present work, 
it is strongly recommended to include the use of Geographic Information Systems and maps for mapping the results on the area and to find possible spatial correlations.

Encourage LGU's, resort owners and the community to provide venues for coastal activities such as clean-up campaigns and support for information dissemination as well as promote the participation of various stakeholders in discussion on coastal planning and conservation.

Promote and support the government's advocacy in environment protection specifically the projects of the Davao Gulf Management Council in the protection and conservation of Davao Gulf as well as create, enhance and provide for strict implementation of coastal laws, regulations, and programs.

\section{Acknowledgments}

The author expresses her grateful appreciation to the Commission on Higher Education (CHED) Zonal Research Center-XI for funding this research endeavor; to the Davao Doctors College Biology and Research Departments for providing insights and guidance throughout the course of this project; Dr. Lucila T. Lupo, Ms. Geonyzl L. Alviola and Ms. Erlyn Jessie D. Dy for their technical assistance; Mrs. Nicefora L. Tubera and Mrs. Zeny B. Egut for the encouragement and support. Research collaborators and DDC BS Biology alumni for conducting the field work activities and data gathering with the author and some biodiversity data.

\section{References}

Ajao, E. A., Oyewo, E. O., \& Uyimadu, J. P. (1996). A review of the pollution of coastal waters in Nigeria. Nigerian Institute for Oceanography \& Marine Research Technical Paper No. 107.

Anonymous. (2006). Davao City Coastal Zone Management Situation and Recommendations. Davao City, Philippines.

Anonymous. (ND). Davao City Geography. Retrieved May 1, 2011, from http://www.travelph.com/resorts/davao

Anonymous. (ND). Davao Doctors College Biology Department Ecology Laboratory Manual. Revised SY 2006-2007. Davao City.

Anonymous. (ND). DENR Administrative Order \#34. Revised Water Usage and Classification/Water Quality Criteria.

Anonymous. (ND). Going Extra Mile for Davao Gulf. Retrieved May 1, 2012 from http://www.sunstar.com.ph//2011/davao/lifestyle07/26/going-extra-mile-davao-gulf-169174

Anonymous. (ND). Philippine Environmental Governance 2 Project. Assessed on May 1, 2011 from www.ecogovproject.denr.gov.ph

Bajunid, F. (ND). Hunter-Central Rivers Waterwatch - Hunter-Central Rivers Catchment Management Authority. Retrieved May 1, 2011, from www.waterwatch.nsw.gov.au

Balogun, K. J, Ladigbolu, I. A., \& Ariyo, A. A. (2011). Ecological assessment of a coastal shallow lagoon in Lagos, Nigeria: A bio-indicator approach. Journal of Applied Science and Environmental Management, 15(1), 41-46. http://dx.doi.org/10.4314/jasem.v15i1.65673

Bleakley, C. (2004). Review of critical marine habitats and species in the Pacific islands region. Samoa: SPREP.

Bos, A., Gumanao, G., Alipoyo, J., \& Cardona, L. (2008). Population dynamics, reproduction and growth of the Indo-Pacific horned sea star, Protoreaster nodosus (Echinodermata; asteroidea). Marine Biology, 156, 55-63.http://dx.doi.org/10.1007/s00227-008-1064-2

Brown, R. L., Jacobs, L. A., \& Peet, R. K. (2007). Species Diversity: Small Scale. Encyclopedia of Life Sciences. http://dx.doi.org/10.1002/9780470015902.a0020488

Capili, E. B., Ibay, A. C. S., \& Villarin, J. R. T. (2005). Climate Change Impacts and Adaptation on Philippine Coasts. Proceedings of the International Oceans 2005 Conference (pp. 1-8). 19-23 September 2005, Washington D.C., USA. http://dx.doi.org/10.1109/OCEANS.2005.1640108

Fenner, B. (2009). Sea Stars: Class Asteroidea. Retrieved March 24, 2009 from $\mathrm{http} / / / \mathrm{www} . w e t w e b m e d i a . c o m /$ seastars.htm

Freeman, S. M. (2005). Asteroidea (Sea Stars). Grzimek's Animal Life Encyclopedia. The Gale Group, Inc. Retrieved Jan. 9, 2009, from http://www.answers.com/topic/asteroidea-sea-stars-biological-family 
Gordon, S., \& Patuawa, T. (2009). Treasures of the Sea: Sea Stars, Sea Urchins, and Sea Cucumbers (Phylum Echinodermata). Retrieved February 1, 2009 from, http://www.treasuresofthesea.org. nz/sea-stars-sea-urchins-and-sea-cucumbers

Himmelman, J., \& Dutil, C. (1991). Distribution, population structure and feeding of subtidal seastars in the Northern Gulf of St. Lawrence Marine Ecology Progress Series, 76, 61-72. http://dx.doi.org/10.3354/ meps076061

Ketcham, B. (2001). Benthic Macroinvertebrate Analysis of Twelve Sites in Point Reyes National Seashore Using the California Stream Bioassessment Procedure. Point Reyes National Seashore, Point Reyes Station, CA 94956.

Klem, D. J. (1990). Macroinvertebrate field and laboratory methods for evaluating the biological integrity of surface waters. Environmental monitoring systems laboratory. US environmental protection agency. Cincinnati, Ohio.

Leighton, B. (1995). Investigating the impact of seastar disease. Retrieved from http://www.sfu.ca/ science /media/seastar.html.

Mah, C. (2008). World Asteroidea Database. Retrieved September 1, 2010, from http://www.marinespecies.org/ Asteroidea

Mueller, B. (2008). Migration of common starfishes in the shallow waters of Samal Island, the Philippines. Germany: University of Rostock.

Paterson, C. (2008). Wetland, Flora, Fauna and Processes. Retrieved February 1, 2009, from $\mathrm{http} / / / \mathrm{www}$. unepscs.org/index.php?option=com_content\&task=view\&id $=462$

Scheibling, R., \& Metaxas, A. (2008). Abundance, spatial distribution, and size structure of the sea star Protoreaster nodosus in Palau, with notes on feeding and reproduction. Bull Mar Sci, 82, 211-235.

Schoppe, S. (2000). A guide to common shallow sea stars, brittle stars, sea urchins, sea cucumbers and feather stars (Echinoderms) of the Philippines. Singapore: Times Media Private Limited.

Young, T. (2011). Biodiversity calculator. Retrieved February 14, 2011, from www.alyoung.com/labs/bio diversity.calculator.html

\section{Appendix A}

Table A1. Species Richness and Distribution of Sea stars

\begin{tabular}{|c|c|c|c|c|}
\hline$\underset{\left(2000 \mathrm{~m}^{2}\right)}{\text { Area }}$ & Species observed & $\begin{array}{c}\text { total \# of } \\
\text { organisms }\end{array}$ & $\begin{array}{l}\text { species } \\
\text { richness }\end{array}$ & $\begin{array}{c}\text { species } \\
\text { diversity } \\
\text { index }\end{array}$ \\
\hline 1 & Astropecten polyacanthus & 325 & 0.06 & 0 \\
\hline 2 & Astropecten polyacanthus & 42 & 0.15 & 0 \\
\hline 3 & $\begin{array}{c}\text { Astropecten polyacanthus, } \\
\text { Protoreaster nodosus, Nordoa spp. }\end{array}$ & 1488 & 0.10 & 0.102 \\
\hline \multicolumn{5}{|l|}{4} \\
\hline \multicolumn{5}{|l|}{5} \\
\hline 6 & $\begin{array}{c}\text { Linkia laevegata, Culcita novaeguineae, } \\
\text { Acanthaster planci, Protoreaster nodosus, } \\
\text { Astropecten polyacanthus }\end{array}$ & 448 & 0.24 & 0.197 \\
\hline 7 & Linckia laevigata, Astropecten polyacanthus & 26 & 0.39 & 0.429 \\
\hline 8 & Linckia laevigata, Astropecten polyacanthus & 16 & 0.50 & 0.377 \\
\hline 9 & Linckia laevigata,, Choriaster granulatus & 12 & 0.87 & 0.918 \\
\hline 10 & & & & \\
\hline
\end{tabular}




\section{Appendix B}

Table B1. Habitat type of the Sampling Areas

\begin{tabular}{|c|c|c|c|c|c|c|c|c|c|c|}
\hline & Area 1 & Area 2 & Area 3 & Area 4 & Area 5 & Area 6 & Area 7 & Area 8 & Area 9 & Area 10 \\
\hline $\begin{array}{l}\text { Habitat } \\
\text { Type }\end{array}$ & $\begin{array}{l}\text { Sandy } \\
\text { with } \\
\text { coral } \\
\text { rubble }\end{array}$ & $\begin{array}{l}\text { Sandy } \\
\text { with } \\
\text { coral } \\
\text { rubble }\end{array}$ & $\begin{array}{l}\text { Sandy } \\
\text { with } \\
\text { seagrass } \\
\text { beds }\end{array}$ & $\begin{array}{l}\text { Silt } \\
\text { and } \\
\text { muddy }\end{array}$ & $\begin{array}{l}\text { Silt } \\
\text { and } \\
\text { muddy }\end{array}$ & $\begin{array}{l}\text { Sandy } \\
\text { with } \\
\text { living } \\
\text { corals }\end{array}$ & $\begin{array}{l}\text { Sandy } \\
\text { with } \\
\text { seagrass } \\
\text { patches }\end{array}$ & $\begin{array}{l}\text { Sandy } \\
\text { with } \\
\text { seagrass } \\
\text { patches }\end{array}$ & $\begin{array}{l}\text { Sandy } \\
\text { with } \\
\text { coral } \\
\text { rubble }\end{array}$ & $\begin{array}{l}\text { Sandy } \\
\text { with } \\
\text { seagrass } \\
\text { patches }\end{array}$ \\
\hline
\end{tabular}

\section{Copyrights}

Copyright for this article is retained by the author(s), with first publication rights granted to the journal.

This is an open-access article distributed under the terms and conditions of the Creative Commons Attribution license (http://creativecommons.org/licenses/by/3.0/). 